\title{
STUDIES ON STORED CEREAL DEGRADATION BY ALTERNARIA TENUISSIMA
}

\author{
Stephen O. Fapohunda and O. O. Olajuyigbe \\ Babcock University, Department of Basic and Applied Sciences \\ Ilishan Remo, Ogun State, Nigeria \\ oystak@yahoo.co.uk
}

\begin{abstract}
The ability of a strain of Alternaria tenuissima Kunze (IMI 301005) Wiltshire to degrade and alter the nutrient profile of three common Nigerian cereals was studied. The grains involved were Pennisetum glaucum, Sorghum vulgare and Oryza sativa. Fat, fibre and protein decreased in the inoculated substrates, and this was accompanied by an increase in ash content. The highest levels of cereal degradation by the mould were attained at $\mathrm{pH} 6.8$ and at temperature range of $30-35{ }^{\circ} \mathrm{C}$. Within 48 hours of incubation, extracellular proteases were detected in all the culture media.
\end{abstract}

Key words: Alternaria tenuissima, cereal, nutrient's degradation.

\section{RESUMEN}

Se estudió la habilidad de una cepa de Alternaria tenuissima Kunze (IMI 301005) Wiltshire de degradar y alterar el perfil de nutrientes de tres cereales nigerianos comunes. Los granos seleccionados fueron Pennisetum glaucum, Sorghum vulgare y Oryza sativa. Las grasas, fibras y proteínas disminuyeron en los sustratos inoculados, hecho acompañado de un incremento en el contenido de ceniza. Los niveles más altos de degradación de cereal por el hongo (moho) se obtuvieron en cultivos con $\mathrm{pH}$ de 6.8 en un intervalo de temperatura de $30-35^{\circ} \mathrm{C}$. A partir de las 48 horas de incubación se detectaron proteasas extracelulares en todos los medios de cultivo.

Palabras clave: Alternaria tenuissima, cereal, degradación de nutrientes. 


\section{INTRODUCTION}

Cereals are important staple foods in Nigerian homes, and their biological value on the basis of nutrient components has been documented (Oyenuga, 1968). The characteristic relatively high environmental temperatures and humidities of the tropic further worsen the integrity of stored grains, under fungal attack whether whole or in blended state (Christensen and Kaufmann, 1969). The interrelationship between Alternaria species and some substrates had also been recorded (Sulaiman and Hussain, 1984; Sanchis et al., 1993; Samson et al., 1995; Pettybridge et al., 2001; Grishkan et al., 2003; Osono, 2003) and the dangers this can pose to man, as a consumer, highlighted (Fapohunda and Ogundero, 1990).

The dangers include toxin consumption and malnutrition arising from consuming grains having a depleted nutrient profile. Alternaria contamination specifically leads to sinusitis, hay fever, skin infection and asthma, these body reactions, being the combined results of accumulation of spores and the production of "alternariol", a unique mycotoxin in the body (Shresthra et al., 1996). The general health implications of the attendant mycotoxins on the affected cereals and on the likely consumer are well documented (Fink-Grennels, 1999; Steyn and Stander, 1999). In 1998, Nielsen et al. had discovered that various forms of mycotoxins on artificially inoculated building materials resulted in cancerous expressions among persons directly exposed to them. The same year, Ren et al. demonstrated the destructive effects on the organs of those who were in contact with ceiling tiles infected by Alternaria alternata. Also, Alternaria species have been reported as mycodeteriogens in some cereals in the field (Ilhan and Asan, 2001). Health implications include cancer of the liver, digestive complications and respiratory difficulties (Zureik et al., 2002).

Millet (Pennisetum glaucum (L.) Leeke), guinea corn (Sorghum vulgare (L.) Moench) and rice (Oryza sativa L.) constitute a group of grains eaten daily by a large number of Nigerians from peasants through the elites. The aim of this study is to highlight the unique role of a strain of Alternaria tenuissima in the bio-degradation of cereals under the stated conditions.

\section{MATERIALS AND METHODS}

A strain of Alternaria tenuissima Kunze Wiltshire IMI 301005, was maintained by growing in a sporulation medium described earlier (Fapohunda, 1992). All sterilizations before inoculation were done at $121{ }^{\circ} \mathrm{C}$ for 15 minutes. 
Fifty grains each of the cereals: millet, guinea corn and rice, purchased from markets in South Western Nigeria, were selected for experimentation after conducting viability tests on them by earlier methods (Huff, 1980; Okafor and Aniche, 1980). Also, the grain samples were held at $0{ }^{\circ} \mathrm{C}$ for 92 hours to kill any mites present, as mites are primary source of cross contamination in a mycology laboratory. Surface sterilization was carried out by dipping inside $2 \% \mathrm{NaOCl}$ for 1 minute and rinsing with distilled water.

Twenty grams of blended grains were placed in flask and $50 \mathrm{ml}$ distilled water added to make a suspension. The fungus was cultivated on nutrient broth for seven days and filtered with sterile cotton wool. Dilution of the filtrate was carried out to give $3.5 \times 10^{6}$ conidia $/ \mathrm{ml}$. These asexual spores serve as inoculum for the blended grains and incubation was at $28{ }^{\circ} \mathrm{C}$ for 14 days. The biochemical analyses expressed as $\%$ ash, crude fibre, protein and fat and moisture contents were determined (Anonymous, 1975) using dry samples. The initial moisture content, which was critical to mould invasion, was also determined. Controls were set up with no inoculum.

The $\mathrm{pH}$ of a 2:1 (w/v) suspension of blended grains in $250 \mathrm{ml}$ conical flasks, containing $100 \mathrm{ml} /$ flask, were adjusted with $0.1 \mathrm{~N}-\mathrm{NaOH}$ or $0.1 \mathrm{~N}-\mathrm{HCl}$, as appropriate, to $\mathrm{pH}$ values between 3.8-7.6. $\mathrm{pH}$ stability was controlled by citric acid phosphate buffers (Ogundero, 1981). Also, the effect of temperature $\left(15-35^{\circ} \mathrm{C}\right)$ on the biodegrading ability of the Alternaria tenuissima was tested by incubating cultures at $5{ }^{\circ} \mathrm{C}$ intervals. For each treatment, three replicates were prepared and incubation was done as earlier described. The $\%$ ash, crude fibre, protein and fat contents were equally determined as described above after seven days of incubation. Uninoculated flasks similarly treated served as controls.

Suspensions of the cereals were prepared ( $15 \mathrm{~g} /$ litre) in distilled water. Four grams of casein and $30 \mathrm{ml}$ portion of the suspension were dispensed in $250 \mathrm{ml}$ conical flasks, and inoculation carried out as described earlier. Three replicates were made and incubation was at $35^{\circ} \mathrm{C}$ and over a 10 -day period. At 2-day intervals, protease activity of the culture filtrate was determined, while using filtrates from the control flasks as assay blanks. The protein contents of the filtrates were also determined using the Folin phenol reagent method of Lowry et al. (1951). The Folin phenol reaction was designed to detect proteolysis as carried out by enzyme protease and the residues include tyrosine, which was measured in this research.

\section{RESULTS AND DISCUSSION}

Fat, fibre and protein decreased in the inoculated substrate with a significant increase in ash (Table 1). The ash content increased as other materials were utilized. 
Table 1. Biochemical analysis of cereal substrates inoculated with conidia of Alternaria tenuissima and incubated for 14 days at $28^{\circ} \mathrm{C}$.

\begin{tabular}{|l|c|c|c|c|c|c|}
\hline $\begin{array}{c}\text { Composition } \\
(\%)^{*}\end{array}$ & \multicolumn{2}{|c|}{ Millet } & \multicolumn{2}{c|}{ Sorghum } & \multicolumn{2}{c|}{ Rice } \\
\hline & $\begin{array}{c}\text { Not } \\
\text { inoculated }\end{array}$ & Inoculated & $\begin{array}{c}\text { Not } \\
\text { inoculated }\end{array}$ & Inoculated & $\begin{array}{c}\text { Not } \\
\text { inoculated }\end{array}$ & Inoculated \\
\hline Ash & $13.00 \pm 0.24$ & $16.80 \pm 0.18$ & $6.05 \pm 0.34$ & $15.68 \pm 0.01$ & $5.98 \pm 0.11$ & $11.11 \pm 0.08$ \\
\hline Crude fibre & $3.61 \pm 0.01$ & $3.01 \pm 0.22$ & $2.65 \pm 0.02$ & $1.90 \pm 0.25$ & $1.26 \pm 0.30$ & $1.05 \pm 0.05$ \\
\hline Protein & $3.68 \pm 0.20$ & $2.08 \pm 0.01$ & $7.01 \pm 0.09$ & $4.12 \pm 0.05$ & $6.08 \pm 0.16$ & $3.86 \pm 0.06$ \\
\hline Fat & $2.11 \pm 0.63$ & $1.18 \pm 0.45$ & $3.22 \pm 0.70$ & $2.67 \pm 0.12$ & $3.01 \pm 0.17$ & $2.51 \pm 0.02$ \\
\hline Moisture & $7.25 \pm 0.10$ & $9.89 \pm 0.11$ & $10.56 \pm 0.08$ & $15.60 \pm 0.02$ & $8.89 \pm 0.04$ & $13.68 \pm 0.04$ \\
\hline
\end{tabular}

${ }^{*}$ Results and means of three replicates

High fibre content had been noted in most cereals (Oyenuga, 1968), which, together with the available protein and fat formed ready substrates on which fungal enzymes acted. This accounted for the reduction in the relative quantities for fibre, protein and fat (Filtenborg et al., 1996). Alternaria spp. had earlier been implicated in the degradation of crops like melon in store by decreasing the germination percentage and increasing the risk of mycotoxicosis (Bankole et al., 1999). The highest percent reduction in protein was recorded when rice was the substrate, followed by sorghum, whereas millet gave the highest percent reduction in fat contents (Table 1). Appreciable increase in water content, which was recorded in all the inoculated cereals, was in normal response to fungal respiration in an environment of oxygen.

Optimization of $\mathrm{pH}$ and temperature regimes

When the effect of $\mathrm{pH}$ on mould degradation was investigated on the cereals, pH 6.8 proved optimal for all nutrients particularly protein (Table 2). Table 3 shows 
S. Fapohunda \& O. O. Olajuyigbe : Stored cereal degradation by Alternaria tenuissima

\begin{tabular}{|c|c|c|c|c|c|c|c|c|c|c|c|c|}
\hline$\underset{r}{0}$ & $\begin{array}{l}8 \\
8 \\
0 \\
1 \\
\infty \\
0 \\
0\end{array}$ & $\begin{array}{l}0 \\
\dot{0} \\
+1 \\
\infty \\
0 \\
0\end{array}$ & $\begin{array}{l}0 \\
0 \\
0 \\
+1 \\
\stackrel{1}{0} \\
=\end{array}$ & $\begin{array}{l}8 \\
0 \\
0 \\
+1 \\
0 \\
0\end{array}$ & $\begin{array}{l}0 \\
0 \\
0 \\
+1 \\
\infty \\
0 \\
r\end{array}$ & $\begin{array}{l}0 \\
\dot{0} \\
\dddot{1} \\
= \\
=\end{array}$ & $\begin{array}{l}0 \\
\dot{0} \\
+1 \\
0 \\
0 \\
0\end{array}$ & $\begin{array}{l}8 \\
8 \\
0 \\
+1 \\
\infty \\
0 \\
0\end{array}$ & $\begin{array}{l}0 \\
0 \\
0 \\
+1 \\
0 \\
0 \\
\dot{0}\end{array}$ & $\begin{array}{l}0 \\
0 \\
0 \\
+1 \\
0 \\
0 \\
-1\end{array}$ & $\begin{array}{l}0 \\
0 \\
0 \\
+1 \\
0 \\
0 \\
-\end{array}$ & $\begin{array}{l}0 \\
\dot{0} \\
+1 \\
\stackrel{n}{\alpha} \\
\dot{m}\end{array}$ \\
\hline$\stackrel{\infty}{0}$ & 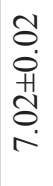 & $\begin{array}{l}0 \\
0 \\
0 \\
+1 \\
\infty \\
\infty \\
-1\end{array}$ & $\begin{array}{l}0 \\
0 \\
0 \\
+1 \\
0 \\
0 \\
=\end{array}$ & 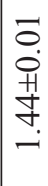 & $\begin{array}{l}3 \\
0 \\
0 \\
+1 \\
\infty \\
\end{array}$ & $\begin{array}{l}\text { ป̄ } \\
\dot{0} \\
+1 \\
0 \\
\infty \\
-1\end{array}$ & $\begin{array}{l}= \\
0 \\
+1 \\
0 \\
\infty \\
=\end{array}$ & $\begin{array}{l} \pm \\
0 \\
0 \\
+1 \\
0 \\
0 \\
-\end{array}$ & $\begin{array}{l}\exists \\
\ddot{0} \\
\ddot{H} \\
\exists \\
\dot{\nabla}\end{array}$ & $\begin{array}{l}= \\
\vdots \\
+1 \\
\text { ㅇ } \\
\text { I. }\end{array}$ & $\begin{array}{l}0 \\
0 \\
0 \\
+1 \\
0 \\
0 \\
\text { I. }\end{array}$ & $\begin{array}{l}\circ \\
0 \\
0 \\
+1 \\
\text { ஹे } \\
\text { ஸे }\end{array}$ \\
\hline ชֶ & $\begin{array}{l}0 \\
0 \\
0 \\
+1 \\
0 \\
0 \\
0\end{array}$ & $\begin{array}{l}\hat{0} \\
\dot{0} \\
+1 \\
0 \\
\dot{0} \\
\text { i }\end{array}$ & 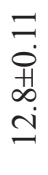 & $\begin{array}{l}0 \\
0 \\
0 \\
0 \\
0 \\
0 \\
-1\end{array}$ & 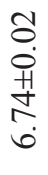 & $\begin{array}{l}0 \\
\ddot{0} \\
\stackrel{+}{+} \\
0 \\
\dot{0}\end{array}$ & $\begin{array}{l}m \\
\stackrel{0}{0} \\
+1 \\
0 \\
\dot{I}\end{array}$ & 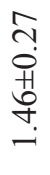 & $\begin{array}{l}\vec{N} \\
0 \\
+ \\
0 \\
0 \\
\dot{\gamma}\end{array}$ & 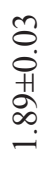 & $\begin{array}{l}= \\
\vdots \\
0 \\
+1 \\
\infty \\
\infty \\
\end{array}$ & $\begin{array}{l}\hat{0} \\
0 \\
+ \\
+ \\
0 \\
\text { r. }\end{array}$ \\
\hline 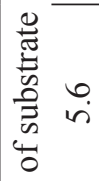 & $\begin{array}{l}0 \\
0 \\
0 \\
+1 \\
\text { Oे } \\
\dot{+}\end{array}$ & $\begin{array}{l}n \\
0 \\
0 \\
1 \\
1 \\
0 \\
0 \\
ن\end{array}$ & $\begin{array}{l} \\
0 \\
0 \\
+1 \\
8 \\
\dot{0} \\
\dot{d}\end{array}$ & $\begin{array}{l}= \\
\ddot{0} \\
+1 \\
2 \\
0 \\
\dot{1}\end{array}$ & $\begin{array}{l}3 \\
0 \\
0 \\
+1 \\
\infty \\
0 \\
\dot{+}\end{array}$ & $\begin{array}{l}\infty \\
0 \\
0 \\
+1 \\
\infty \\
n \\
i\end{array}$ & 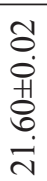 & $\begin{array}{l}\infty \\
0 \\
0 \\
+ \\
+ \\
\infty \\
\stackrel{+}{+}\end{array}$ & 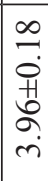 & $\begin{array}{l} \\
0 \\
+ \\
+ \\
\infty \\
\infty\end{array}$ & $\begin{array}{l}0 \\
0 \\
0 \\
+1 \\
8 \\
\infty \\
\infty\end{array}$ & $\begin{array}{l}\hat{0} \\
\dot{0} \\
+1 \\
\infty \\
0 \\
\dot{m}\end{array}$ \\
\hline$\stackrel{\infty}{+}$ & $\begin{array}{l}\overrightarrow{0} \\
\dot{0} \\
+1 \\
0 \\
-\end{array}$ & 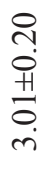 & $\begin{array}{l}\infty \\
0 \\
0 \\
+1 \\
\infty \\
\infty \\
\dot{\nu}\end{array}$ & 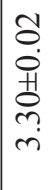 & $\begin{array}{l} \\
0 \\
0 \\
+1 \\
8 \\
\dot{8} \\
\dot{m}\end{array}$ & $\begin{array}{l}0 \\
0 \\
+ \\
+1 \\
0 \\
0 \\
ن\end{array}$ & $\begin{array}{l}\qquad \\
0 \\
0 \\
+1 \\
\infty \\
\infty \\
\dot{d}\end{array}$ & 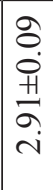 & $\begin{array}{l}0 \\
\dot{0} \\
+1 \\
\dot{1} \\
\infty \\
\dot{\infty}\end{array}$ & 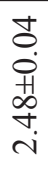 & $\begin{array}{l}\text { Õ } \\
0 \\
0 \\
+1 \\
8 \\
o \\
\dot{ர}\end{array}$ & $\begin{array}{l} \\
\stackrel{0}{\circ} \\
+1 \\
8 \\
\dot{+}\end{array}$ \\
\hline$\stackrel{\infty}{\infty}$ & 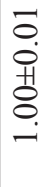 & 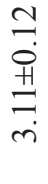 & $\begin{array}{l}\stackrel{8}{\infty} \\
\dot{0} \\
+ \\
0 \\
+ \\
\dot{0}\end{array}$ & $\begin{array}{l}0 \\
0 \\
0 \\
+1 \\
0 \\
n \\
n\end{array}$ & $\begin{array}{l}0 \\
0 \\
+ \\
+ \\
\infty \\
0 \\
-1\end{array}$ & $\begin{array}{l}0 \\
\dot{0} \\
+1 \\
6 \\
\dot{0}\end{array}$ & 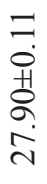 & $\begin{array}{l}+ \\
0 \\
0 \\
+1 \\
0 \\
\dot{m}\end{array}$ & $\begin{array}{l}2 \\
0 \\
0 \\
+1 \\
0 \\
0 \\
\dot{1}\end{array}$ & 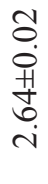 & 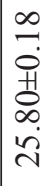 & 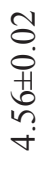 \\
\hline $\begin{array}{l}\frac{0}{\Xi} \\
\frac{\pi}{2} \\
0 \\
0 \\
0 \\
0 \\
0\end{array}$ & $\begin{array}{l}= \\
\vdots \\
+ \\
1 \\
\infty \\
0 \\
0\end{array}$ & 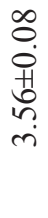 & 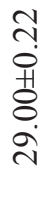 & $\begin{array}{l}0 \\
0 \\
0 \\
+1 \\
0 \\
0 \\
\dot{0}\end{array}$ & 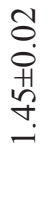 & $\begin{array}{l}\infty \\
0 \\
0 \\
+1 \\
0 \\
\dot{0} \\
\dot{m}\end{array}$ & $\begin{array}{l}\infty \\
\dot{0} \\
+1 \\
\frac{1}{2} \\
\frac{\pi}{n}\end{array}$ & $\begin{array}{l}= \\
0 \\
0 \\
\dot{1} \\
\infty \\
\dot{m}\end{array}$ & $\begin{array}{l}0 \\
0 \\
0 \\
+1 \\
0 \\
\infty \\
-1\end{array}$ & $\begin{array}{l}0 \\
0 \\
0 \\
+1 \\
\infty \\
\infty \\
i\end{array}$ & $\begin{array}{l}\infty \\
0 \\
0 \\
+ \\
0 \\
0 \\
0 \\
\infty \\
\text { ஸे }\end{array}$ & 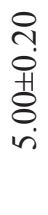 \\
\hline 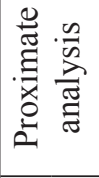 & 苄 & 总 & $\begin{array}{l}\frac{7}{0} \\
\frac{0}{0} \\
0\end{array}$ & 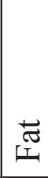 & $\frac{\tilde{n}}{4}$ & 总 & 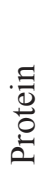 & 䒕 & $\frac{\pi}{4}$ & 总 & $\mid \begin{array}{l}: \\
0 \\
0 \\
0 \\
2\end{array}$ & $\underset{\pi}{\tilde{T}}$ \\
\hline & \multicolumn{4}{|c|}{ 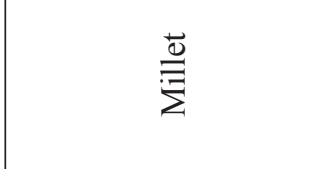 } & \multicolumn{4}{|c|}{ 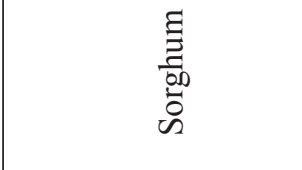 } & \multicolumn{4}{|c|}{ 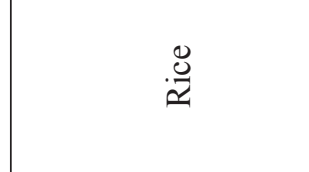 } \\
\hline
\end{tabular}


Acta Botanica Mexicana 77: 31-40 (2006)

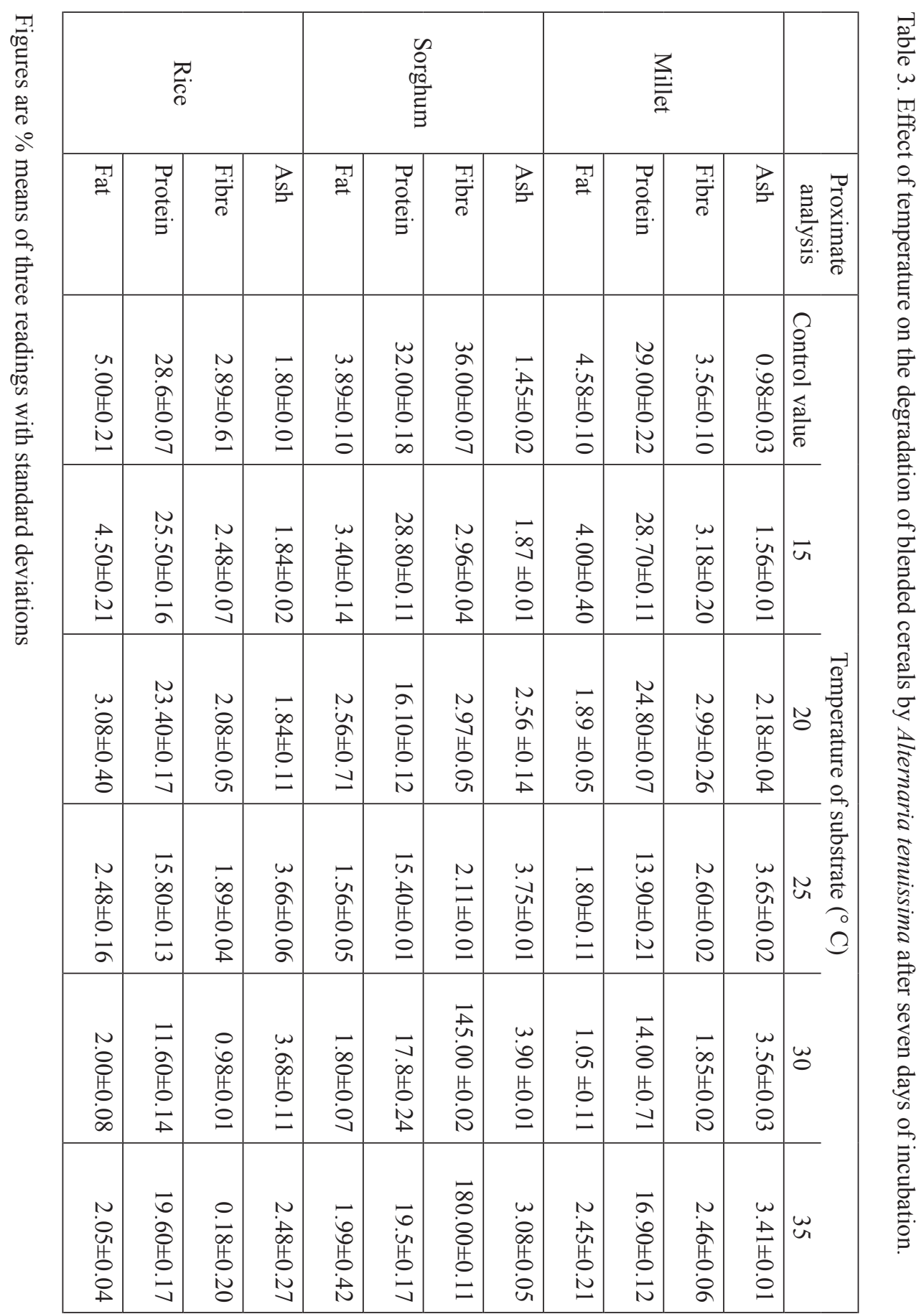


that the temperature range for maximum mould degradation was $25-30{ }^{\circ} \mathrm{C}$. At $15{ }^{\circ} \mathrm{C}$, the ability to breakdown the nutrients decreased. However, with rice as substrate the rate of degradation of fibre was highest at $35^{\circ} \mathrm{C}$. The results showed that fibre content in rice was decreased with an increase in temperature.

\section{Extracellular protease production}

The secretion of protease by the fungus in the presence of the substrates (Fig. 1) explains the high rate of protein degradation under the various $\mathrm{pH}$ and temperature conditions, a significant result. Within 48 hours of inoculation, soluble peptides were excreted in the growth medium (Fig. 2). For rice, protein production fell at day 5. This was not so in the other two cereals where increases were observed until day 5.

Adequate precautions like immersing of the moist grains in $0.5 \%$ propionic acid and potassium sorbate (Liewen and Marth, 1984; Fapohunda, 1992) for a two minutes could be taken to guarantee significant safety and economic advantage to prospective consumers of the grains, while some human pathogenic fungi have been

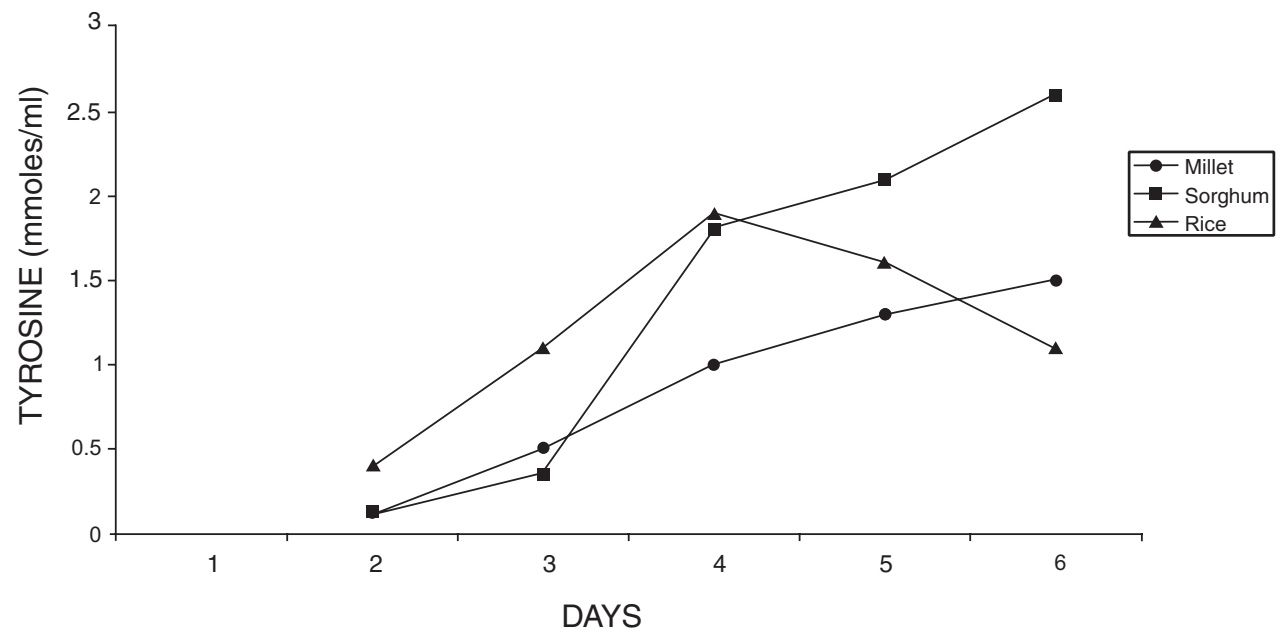

Fig. 1. Protease activity of culture filtrates of Alternaria tenuissima grown on millet, sorghum and rice. 


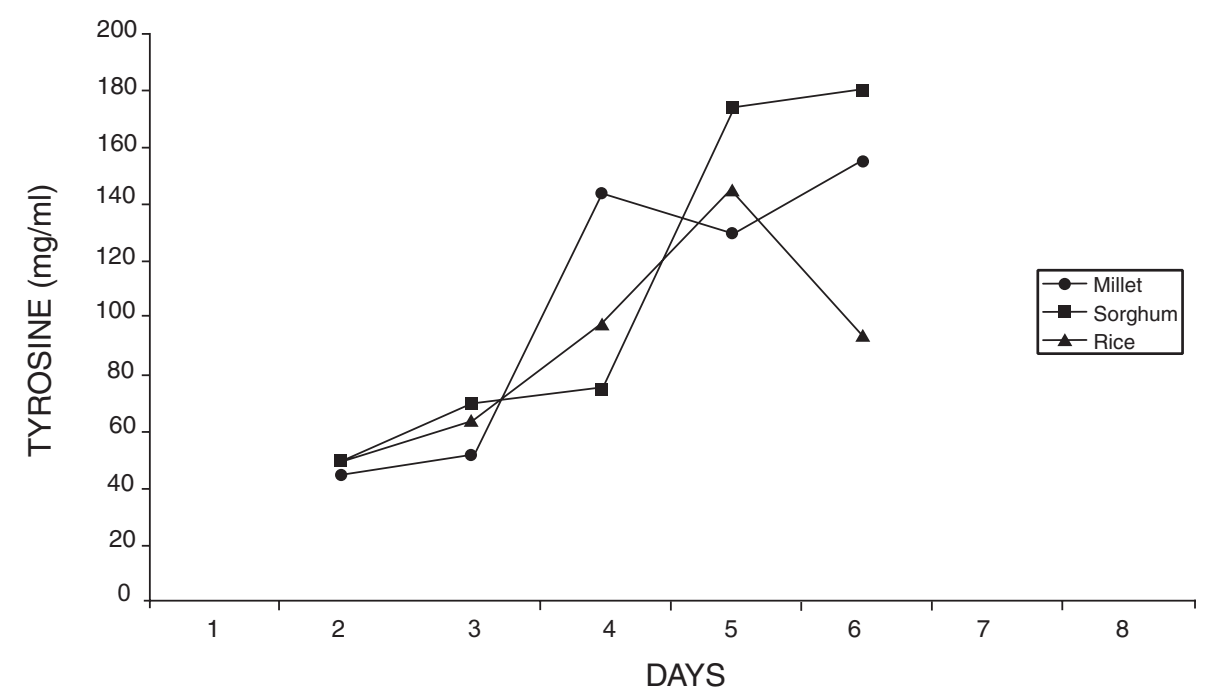

Fig. 2. Protein content of culture filtrates of Alternaria tenuissima grown on millet, sorghum and rice.

known to be inhibited by ethnobotanically selected plant extracts (Brandwagt et al., 2001; Ficker et al., 2003).

We are carrying out further studies on the prevention of fungal contamination, isolation and characterization of specific toxic metabolites using the High Performance Liquid Chromatography (HPLC) and the development of more antifungal agents with respect to this species. Also, the exploitation of inexpensive antifungal plant extracts is attracting further investigation, as some fungi express resistance to synthetic drugs (like propionic acid) and encourage new opportunists in the course of infection (Perfect and Schell, 1996). From this study it is observed that common cereals like sorghum, rice and millet are degraded, among others, by the proteolytic action of the fungus Alternaria tenuissima. The fungus, which incites various body disorders through its spores and toxic metabolites, can be controlled by a brief immersion in $0.5 \%$ propionic acid and sorbate. Since similar microbes had been inhibited by ethnobotanically selected plant extracts from, e.g., ginger and butternut, the next stage of our work is to formulate inexpensive antifungal agents from plant extracts in order that cereals in storage can be fairly safe from its contamination. 


\section{LITERATURE CITED}

Anonymous. 1975. Official methods of analysis. 12th ed. Association of Official Agricultural Chemists, Washington, D. C. 101 pp.

Bankole, S. A., B. Ikotun \& E. J. A. Ekpo. 1999. Fungal deterioration of melon seeds stored in jute sacks and polyethelene bags in Ago Iwoye, South Western Nigeria. Mycopathologia 146(3): 135-146.

Brandwagt, B. F., T. A Kneppers, A. van der Weerden, H. J. Nijkamp \& J. Hille. 2001. Most AAL toxin sensitive Nicotiana species are resistant to the tomato fungal pathogen Alternaria alternata f. sp. lycopersici. Mol. Plant. Microb. 14(4): 460-470.

Christensen, C. M. \& H. H. Kaufmann. 1969. Grain storage - The role of fungi in quality loss. University of Minnesota Press. Minneapolis. $153 \mathrm{pp}$.

Fapohunda, S. O. 1992. Studies in Aspergillus and Cladosporium species infecting stored cereals. Pakistan J. Sci. Ind. Res. 35(9): 335-337.

Fapohunda, S. O. \& V. W. Ogundero. 1990. Physiology of fungi associated with fast foods in Nigeria. Int. Biodeter. J. 26: 23-32.

Ficker, C. E., J. T. Arnason, P. S. Vindas, L. P Alvarez., K. Akpogana, M. Gbeasor, C. De Souza, \& M. L. Smith. 2003. Inhibition of human pathogenic fungi by ethnobotanically selected plant extracts. Mycoses 46 (1-2): 29-37.

Filtenborg, O., V. C. Frisvad \& U. Thrane. 1996. Moulds in food spoilage. Int. J. Food Microbiol. 33: 85-102.

Fink-Grennels, J. 1999. Mycotoxins: Their implications for human and animal health. Vet. Quarterly 21: 115-120.

Grishkan, I.., E. Nevo \& S. P. Wasser. 2003. Soil micromycete diversity in the hypersaline Dead Sea coastal area, Israel. Mycol. Progress 20(1): 19-28.

Huff, W. E. 1980. A physical method for the segregation of aflatoxin-contaminated corn. Cereal Chem. 57(4): 236-238.

Ilhan, S. \& A. Asan. 2001. Soilborne fungi in wheat fields of Kirka vicinity (Turkey). Biologia Bratislava 56: 263-271.

Liewen, M. B. \& E. H. Marth. 1984. Inhibition of penicillia and aspergilli by potassium sorbate. J. Fd. Prot. 47: 554-556.

Lowry, O. H., N. J. Rosebrough, A. J. Farr \& R. J. Randall. 1951. Protein measurement with the Folin-phenol reagent. J. Biol. Chem. 193: 265.

Nielsen, K. F., U. Thrane, T. O. Larsen, P. A. Nielsen \& S. Gravesen. 1998. Production of mycotoxins on artificially inoculated building materials. Int. Biodeter. Biodegr. 42: 8-15.

Ogundero, V. W. 1981. Degradation of Nigerian palm products by thermophilic fungi. Trans. Brit. Mycol. Soc. 77: 267-271.

Okafor, N. \& N. Aniche. 1980. Brewing a lager beer from Nigeria Sorghum. Brewing and Distilling International 10: 32- 35.

Osono, T. 2003. Effects of prior decomposition of beech leaf litter by phyllosphere fungi on substrate utilization by fungal decomposers. Mycoscience 44: 41-45. 
Oyenuga, V. A. 1968. Nigeria's food and feeding stuff. Their chemistry and nutritional value. 1st. ed. Ibadan University Press. Nigeria. pp. 41-44.

Perfect, J. R. \& M. A. Schell. 1996. The newer fungal opportunists are coming. Clin. Infect. Dis. 22 (supp. 2): 112-118.

Pettybridge, S. J., F. J. Hay, C. R. Wilson, L. J. Sheriff \& C. W. Legegatt. 2001. First report of infection of hop cones by Alternaria alternata in Australia. Plant Dis. 85(7): 804.

Ren, P., D. G. Ahearn \& S. A. Crow .1998. Mycotoxins of Alternaria alternata produced on ceiling tiles. J. Ind. Microbiol. 20: 53-54.

Samson, R. A., E. S. Hoekstra, J. C. Frisvad \& D. Filtenborg. 1995. Introduction to food borne fungi. 4th. ed. Central Bureau Voor Schimelcultures. Baarn. 322 pp.

Sanchis, V., A. Sanclementele, J. Usall \& J. Vinas. 1993. Incidence of mycotoxigenic Alternaria alternata and A. flavus in barley. J. Fd. Prot. 56(36): 246-248.

Shresthra, G., A. P. Sharma, S. Geeta \& S. Achyut. 1996. A preliminary study of allergens produced by Alternaria sp. and Aspergillus fumigatus. Ind. J. Allergy Appl. Immunol. 10(1): $5-9$.

Sulaiman, E. D. \& S. S. Hussain. 1984. Pathogenicity and effect on germination caused by Aspergillus and Penicillium species on wheat, rice, barley and corn. Pak. J. Sc. Ind. Res. 27(6): 359-362.

Steyn, P. S. \& M. A. Stander. 1999. Mycotoxins as causal factors of diseases in human. J. Toxicol. Toxin. Rev. 18: 229-243.

Zureik, M., C. Neulck, B. Leynnart, R. Liard, J. Bausquet \& F. Neukirah. 2002. Sanitization to airborne mould and severity of asthma: Cross sectional study from European Community respiratory health survey. Brit. Med. J. 325: 411.

Recibido en junio de 2005.

Aceptado en junio de 2006. 